\title{
Dinâmica de Portfólio dos bancos públicos no período 1995/2010 e uma análise da liberação dos recursos do BNB
}

\author{
Nathália Bizinoto Silva' \\ Vanessa Petrelli Corrêa
}

\begin{abstract}
Resumo: Nosso objetivo neste trabalho foi analisar o comportamento dos bancos públicos, no que tange à sua lógica de oferta de empréstimos no interregno 1995-2010, analisando, mais especificamente, o comportamento do Banco do Nordeste. A compreensão é de que a decisão da oferta de empréstimos dos bancos públicos envolve uma decisão entre aplicações alternativas e isso ocorre mesmo considerando que esses bancos teriam uma lógica particular, definida pela implantação de políticas específicas. A nossa hipótese é que entre 2000 e 2007 , o comportamento dos bancos públicos se dirigiu a uma lógica de maior semelhança com a lógica da atuação dos bancos privados. Paralelamente, após 2008, seria possível verificar uma mudança de performance, com um importante avanço das operações de créditos, quando esses bancos atuam de forma anticíclica. No entanto, a nossa hipótese é a de que esse avanço privilegiou os tomadores "mais seguros", contribuindo para uma maior concentração do perfil dos empréstimos. Os dados desenvolvidos comprovaram essa hipótese.
\end{abstract}

Palavras-chave: Sistema Financeiro Nacional, Bancos Públicos, Banco do Nordeste.

\section{Classificação JEL: E51}

Portfolio dynamics of public banks in the period 1995/2010 and an analysis of the release of $\mathrm{BNB}$ resources

\begin{abstract}
Our goal in this study was to analyze the behavior of public banks in terms of their loans supply logic in the interregnum 1995-2010, analyzing more specifically the Bank of Northeast 's behavior. The understanding is that the public banks lending bid decision involves a choice between alternative applications and this occurs even considering that these banks have a particular logic, defined by the implementation of specific policies. Our hypothesis is that between 2000 and 2007 the behavior of the public banks turned to a logic of similarity to the logic of the performance of private banks. At the same time, after 2008 it would be possible to see a change
\end{abstract}

1 Doutoranda do Programa de Pós-Graduação em Economia da Universidade Federal de Uberlândia. E-mail: nathbizinoto@gmail.com

2 Doutora em Teoria Econômica pela Universidade Estadual de Campinas. Professora Titular do Instituto de Economia da Universidade Federal de Uberlândia. E-mail: vanplli2010@gmail.com 
in performance, with a significant advance of loan operations, when these banks act anti-cyclically. However, our hypothesis is that this advance privileged "more secure" borrowers, contributing to a higher concentration of the loan profile. Developed data confirmed this hypothesis.

Keywords: National Financial System, Public Banks, Bank of Northeast.

\section{Introdução}

O objetivo deste trabalho foi analisar comportamento dos bancos públicos e, inserido nessa discussão, verificar o comportamento do Banco do Nordeste no período 1995 a 2010, em que se observa importante movimento de avanço do crédito no país. A perspectiva adotada é a de considerar que a decisão de ofertar empréstimos não pode ser analisada sem que se considere a dinâmica de ajuste de portfólio dos bancos, na medida em que essa decisão envolve a comparação de aplicações alternativas, dentre elas a de aplicações em Títulos e Valores Mobiliários e, isto, ainda comparado com perspectiva da necessidade de liquidez nos diferentes momentos do ciclo econômico.

Ainda que os Bancos Públicos tenham uma dinâmica particular, a nossa hipótese é a de que após 1999 e até 2007, a lógica de aplicação desses bancos se aproximou mais daquela observada para os Bancos Privados no Brasil, que priorizam operações mais seguras e ainda assim lucrativas, que são as aplicações em Títulos e Valores Mobiliários (TVM). No âmbito das adequações às exigências das regras da Basiléia, os bancos públicos, recentemente, passaram por profundas mudanças em sua forma de atuação, diminuindo o seu volume de crédito concedido e aumentando as aplicações em Títulos e Valores Mobiliários, de forma significativa.

Além disso, outra hipótese que consideramos é a de que houve uma volta da ação mais efetiva de oferta de créditos em detrimento das operações em títulos a partir de 2008, quando os bancos públicos atuaram com um papel anticíclico importante. No entanto, a hipótese é a de que a expansão de recursos nessa fase deu-se privilegiando os tomadores "mais seguros", contribuindo para uma maior concentração do perfil dos empréstimos. Para analisar mais especificamente essa última hipótese, faremos uma análise dos balancetes do Banco do Nordeste, que é um banco eminentemente público.

A perspectiva teórica da análise parte da abordagem de Keynes quanto ao papel do Sistema Bancário, enquanto agentes criadores de moeda, sem depender da poupança passada e tendo um papel crucial na oferta de recursos que afetam as decisões de produzir e especialmente de investir (Keynes, 1992a e 1992b). Mais especificamente, nossa abordagem teórica se articula sob avanço dessa perspectiva apontada por Key- 
nes e que foi desenvolvida por autores pós Keynesianos. Para os propósitos da análise desenvolvida nesse trabalho, utilizam-se especialmente as discussões propostas por Minsky (1986). O autor destaca a importância de se analisar a dinâmica de ativos e passivos dos balancetes bancários para compreender a decisão de ofertar fluxos de crédito. Ademais, destaca-se também o fato de que as posturas financeiras dos agentes (mais ou menos especulativas) dependem do momento do ciclo econômico. Também, inserido na mesma discussão, destaca-se o avanço da operação do Sistema Bancário, mostrando que o mesmo evoluiu, explicitando-se o fato de que, após a década de 1960, consideram-se bancos que atuam com forte diversificação de instrumentos de passivo (possibilitando diferentes formas de geração de liquidez).

Uma das questões fundamentais é a de que o Sistema Bancário privado tem como foco de sua atuação a lógica de lucratividade e, portanto, a oferta de empréstimos fica continuamente relacionada à comparação com aplicações alternativas. No caso específico do Brasil, fica sempre comparada ao potencial de alta lucratividade e baixo risco propiciado pelas aplicações em títulos públicos. Ademais, é possível observar que, historicamente, os recursos direcionados pelo Sistema Financeiro Nacional tenderam a se concentrar nas regiões mais dinâmicas e nos agentes de maior porte.

Nesse contexto é que a análise do comportamento dos Bancos Públicos se torna importante, pois eles poderiam ter uma dinâmica diferenciada. Conforme indicado, a nossa hipótese é a de que esse papel diferenciado se deu especialmente depois de 2008, mas, entre 1995 e 2007, a dinâmica não se diferenciou sobremaneira da apresentada pelos bancos privados.

Para efetuar nossa análise, que se concentrará na análise das principais contas de ativo dos bancos, estabelecemos uma periodicidade, seguindo proposta apresentada em Corrêa (2010). Essa periodicidade está subordinada à dinâmica da liquidez financeira mundial, na medida em que as decisões de aplicação dos agentes (dentre eles os bancos) estão inseridas na dinâmica do ciclo financeiro das finanças globais, como também da dinâmica macroeconômica do país.

Conforme já mencionado, o ponto de partida essencial da análise é o de que o estudo do comportamento dos créditos, ofertados pelos bancos, não pode se dar sem se analisar a lógica de ajuste de portfólio dos mesmos, face às mudanças conjunturais e às perspectivas de variações no ciclo financeiro, considerado na periodização adotada. A partir daí o texto utiliza a periodização e efetua análise das contas de Ativo dos balancetes de Bancos Privados Nacionais, Privados Estrangeiros e Públicos.

Após a análise acima apresentamos o estudo sobre os movimentos das principais contas de ativo do BNB, no sentido de verificar se a dinâmica das mesmas se aproxima do comportamento das contas de ativos do agregado dos bancos públicos no país. Por fim, apresentamos uma avaliação com um maior nível de detalhamento, sobre a performance das operações de crédito de curto prazo e de longo prazo do BNB. Nas considerações finais, estão algumas conclusões a partir do estudo apresentado ao longo deste trabalho. 


\section{Uma análise sobre o ajuste de portfólio dos bancos públicos e pri- vados no Brasil: o comportamento das contas de ativo no período 1995-2010}

O objetivo desta seção consiste em analisar a atuação dos bancos no Brasil, ao longo no interregno 1995-2010, considerando a dinâmica da oferta de crédito. Nosso intuito foi o de relacionar a decisão de liberar esses créditos com aplicações alternativas, especialmente as aplicações em Títulos e Valores Mobiliários e também levando em conta a dinâmica macroeconômica nacional e o ciclo financeiro internacional.

\subsection{A periodicidade adotada}

A periodicidade que levamos em consideração envolve a análise das condições de liquidez internacional, que afetam diretamente a dinâmica macroeconômica de países que não têm moeda forte, mas também considerando a dinâmica macroeconômica nacional.

A partir daí o período sob análise está dividido em quatro fases.

I) A primeira fase está compreendida entre 1994 e 1999, período em que ocorre forte liquidez internacional até basicamente 1998, em que os países da América do Sul estão passando por processos de abertura financeira e em que passaram pela renegociação de suas dívidas externas. No caso específico do Brasil é a fase em que ocorre forte ajuste inflacionário e, em que dinâmica macroeconômica, envolve a adoção de câmbio administrado em situação de abertura financeira com forte diferencial de juros entre os praticados no país e os definidos nos países centrais (especialmente os Estados Unidos). Pode-se considerar que a crise Russa encerra a fase de liquidez e o período em questão se encerra com a adoção do regime de câmbio flutuante no início de 1999.

Durante esse interregno, além dessa última crise, ocorrem também as crises do México (1994) e da Ásia (1997), que afetaram diretamente o país, via efeito contágio. O importante para os propósitos do trabalho é que, nos momentos de reversão de liquidez e de potencial fuga de capitais, a resposta do país é a de um ajuste rápido, para cima, das taxas de juros domésticas, mantendo-se o nível do câmbiỏ3.

A perspectiva é a de que a abertura financeira afeta profundamente a entrada dos fluxos de capitais para os países periféricos, sendo que os movimentos de arbitragem dos grandes capitais são facilitados e afetam fortemente os fluxos para países que não têm moeda forte (Prates, 2002). Nesse sentido, para dirigir recursos a esses países periféricos, em moeda doméstica, os capitais internacionais consideram uma demanda de rentabilidade que cubra o chamado Risco País e o Risco de câmbio (que

3 Para o ajuste das taxas de juros veja-se Garcia e Didier (2003), Miguel (2001). 
engloba a variação esperada do câmbio mais um prêmio de risco). Considerando-se os títulos públicos da dívida interna, teríamos:

\section{$\mathbf{i}$ doméstica $=\mathbf{i}$ internacional + forward premium (risco de câmbio + prêmio de risco)}

Levando em conta essa questão e uma situação de câmbio administrado, a dinâmica utilizada pelas Autoridades Monetárias foi a de reduzir a taxa Selic nos momentos de liquidez, de forma que a mesma cobrisse o nível da taxa internacional de referência (Taxa Treasury dos Estados Unidos) mais o Risco País (podendo ser medido pelo índice Embi +), mas cobrindo apenas uma parte do forward premium. Do lado do câmbio adotou-se um movimento de desvalorização paulatina, seguindo o movimento da inflação (Miguel, 2001). Paralelamente, nos momentos de queda abrupta da liquidez, o Governo manteve o câmbio estabilizado, à despeito das fugas de capitais e o ajuste se deu via juros, em um nível capaz de cobrir o Risco País e o forward premium completo, sendo que todos os riscos evolvidos sobem rapidamente nesses momentos, fortemente influenciados por fatores especulativos.

A estratégia de operação dos bancos será fortemente afetada por essa dinâmica, na medida em que, nos momentos de liquidez, a tendência é a de ofertar mais crédito, aceitando-se maiores níveis de iliquidez. Paralelamente, nos momentos de instabilidade, a tendência é a de reduzir os empréstimos, ajustandose rapidamente pela via de aumento na aplicação em títulos, fato facilitado pela dinâmica de alta rentabilidade oferecida pelos títulos públicos brasileiros ${ }^{4}$.

II) A segunda fase está compreendida entre o segundo semestre de 1999 e 2002, período em que ocorre a mudança da dinâmica do câmbio, passando-se ao regime flutuante e em que se adota, no país, o regime de Metas de Inflação. Essa é uma fase em que ocorrem movimentos de expansão e retração abrupta da liquidez internacional, dirigida à países periféricos e nesse interregno ocorre a crise da Argentina, além dos movimentos de instabilidade do mercado de capitais norte-americano e de ataques terroristas aos Estados Unidos. É um período de "feast or famine" em que a liquidez se expande e se retrai rapidamente (FMI, 2004). Um fato fundamental a comentar é que a dinâmica da política monetária norteamericana afeta fortemente os fluxos dirigidos aos países periféricos e, no Gráfico 1, é possível observar o movimento de expansão, estabilidade e queda da taxa básica norte americana entre 1999 e 2011, observando-se que nessa segunda fase ocorre uma um movimento de queda, que permanece até o início de 2004, quando a trajetória reverte.

4 Mais à frente vamos analisar o ajuste de portfólio dos bancos. 
III) A terceira fase vai do final de 2003 ao primeiro semestre de 2007. Nesses anos, observa-se um movimento expressivo de crescimento da liquidez internacional, com volta mais forte dos fluxos financeiros aos países da América Latina. Há uma queda geral da percepção de riscos, sendo que os índices de Risco País caem em geral e, no Brasil, há uma forte diminuição dos mesmos. A valorização do Real, observada no período, provoca mudanças de estratégias quanto aos indexadores de aplicações e de dívidas. Nessa fase, o Governo reduz sua exposição de dívida cambial, na medida em que o mercado passa a não buscar a aplicação em títulos com correção cambial. É uma fase de redução da Dívida Líquida do Setor Público (DLSP) e de altos níveis de superávit primário do Governo, o que é mais um fator de estabilidade. Ou seja; é uma fase em que se observa uma melhora dos indicadores macroeconômicos brasileiros. Ademais, essa é uma fase de expansão do país, sendo que, do ponto de vista da economia real, as taxas de crescimento brasileiras atingem níveis médios de 4,2\% a.a., patamares superiores aos alcançados nas duas décadas anteriores.

IV) A quarta fase vai do segundo semestre de 2007 até 2011, na qual se encerra nosso estudo. Tomamos o segundo semestre de 2007 como o início de uma nova fase, porque aí se iniciam os primeiros indicadores da Crise de Subprime que vai se aprofundar, de fato, após o segundo semestre de 2008. Nesse último período, podemos indicar de fato subfases. Há períodos de queda mais profunda da liquidez, em 2008 e início de 2009. Com a adoção da política de Quantitative Easing e de queda profunda das taxas de juros norte-americanas, observa-se o retorno da liquidez, considerando que os aplicadores retornam seu "apetite pelo risco", buscando aplicações alternativas nos países periféricos, capazes de geral alta rentabilidade. No caso do Brasil, uma rápida recuperação da economia brasileira e um dos elementos importantes é a ação anticíclica dos investimentos públicos e dos bancos públicos, que foram chamados a ter esta atuação. Esse crescimento permanece, basicamente, até o primeiro semestre de 2011, quando a deterioração do cenário mundial, com o ainda baixo crescimento dos EUA, a dificuldade de recuperação da Europa e o menor crescimento da China afetam as decisões de investimento, fato somado a uma forte redução dos investimentos públicos.

Tendo-se observado a periodização, o próximo passo é apresentar os dados de evolução dos créditos do Sistema Financeiro Nacional e seguir para a análise de ajuste de portfólio dos bancos públicos e privados. Note-se que vários trabalhos já analisaram com bastante rigor o período que vai de 1994 a 2007, mas os dados mais recentes não foram tão detalhados. Quanto ao período que vai até 2007, em nosso trabalho nos baseamos nas interpretações apresentados por Puga (1999), De Paula, Alves Lr. \& Marques (2000), Lima e Corrêa (2009). 
Gráfico 1: Taxa treasury (USA) de 1 ano, diária acumulada em 12 meses

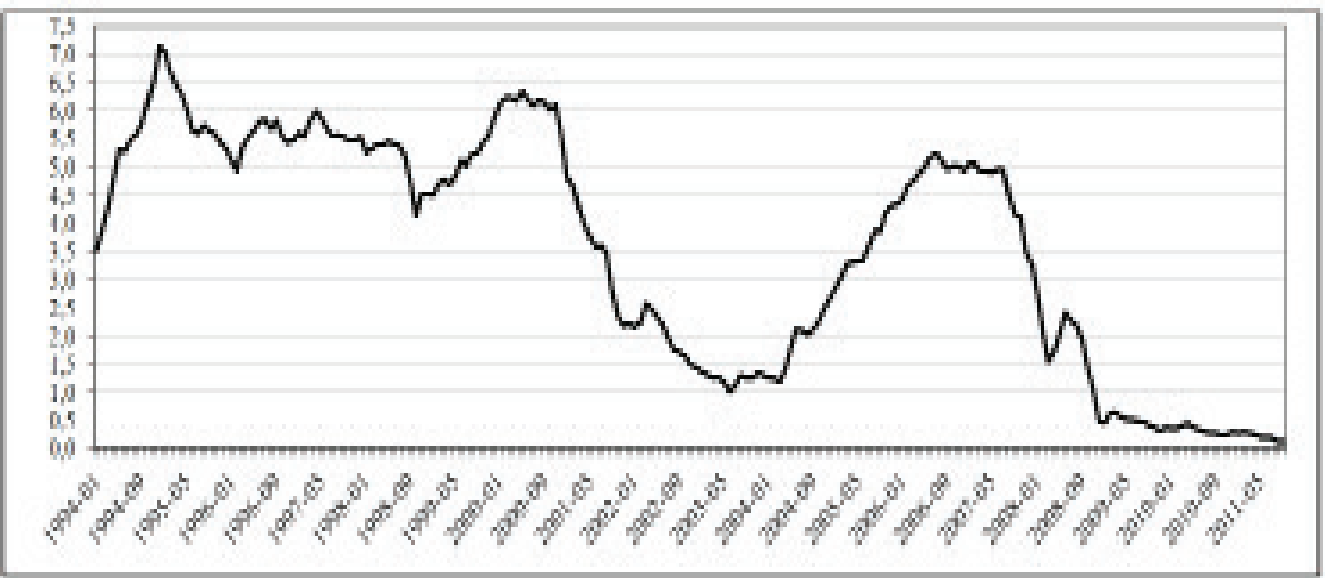

Fonte: Ipeadata

\subsection{A evolução do crédito}

A análise do movimento do crédito constante no Gráfico 2 confirma a periodicidade indicada pelo trabalho. De fato, podemos observar um inicial crescimento das liberações, que é revertida, especialmente, pelo advento das crises da Ásia e da Rússia, seguida pela própria crise do Brasil em 1999. No segundo período considerado (1999-2003), observa-se a redução do crédito, o que vai ser revertido na terceira fase, após 2003.

\section{Gráfico 2: Evolução das operações de crédito totais do sistema financeiro nacional $(1995=100)$}

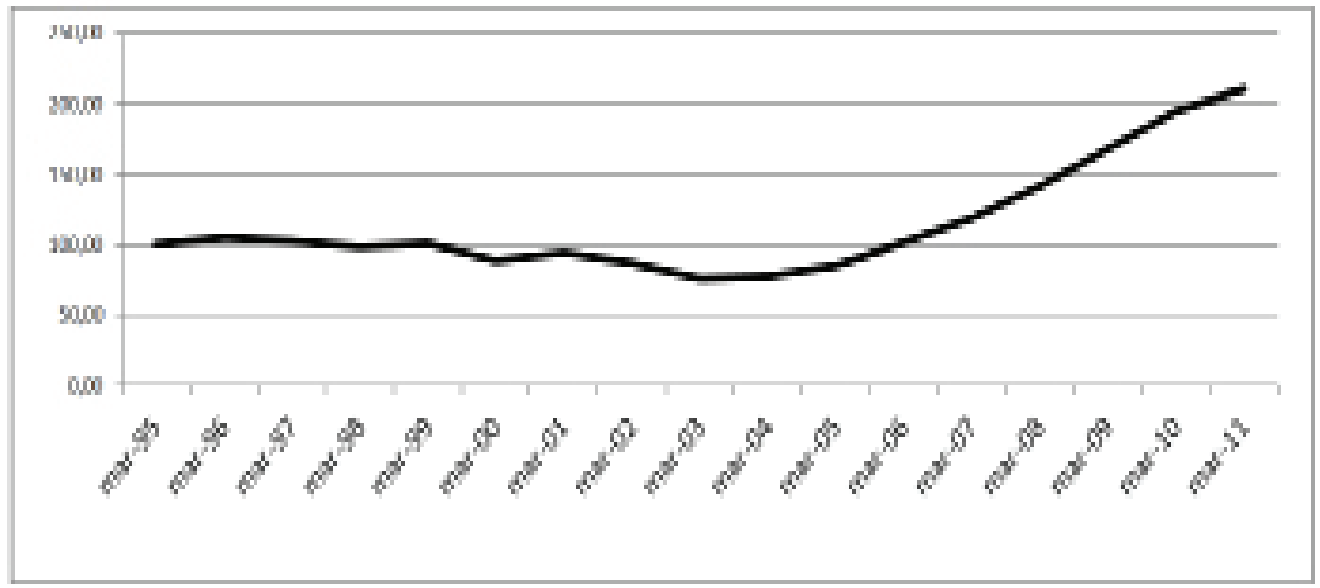

Fonte: Elaboração própria a partir de dados do Banco Central do Brasil, Séries temporais. 
Gráfico 3: Operações de crédito totais (\% PIB)

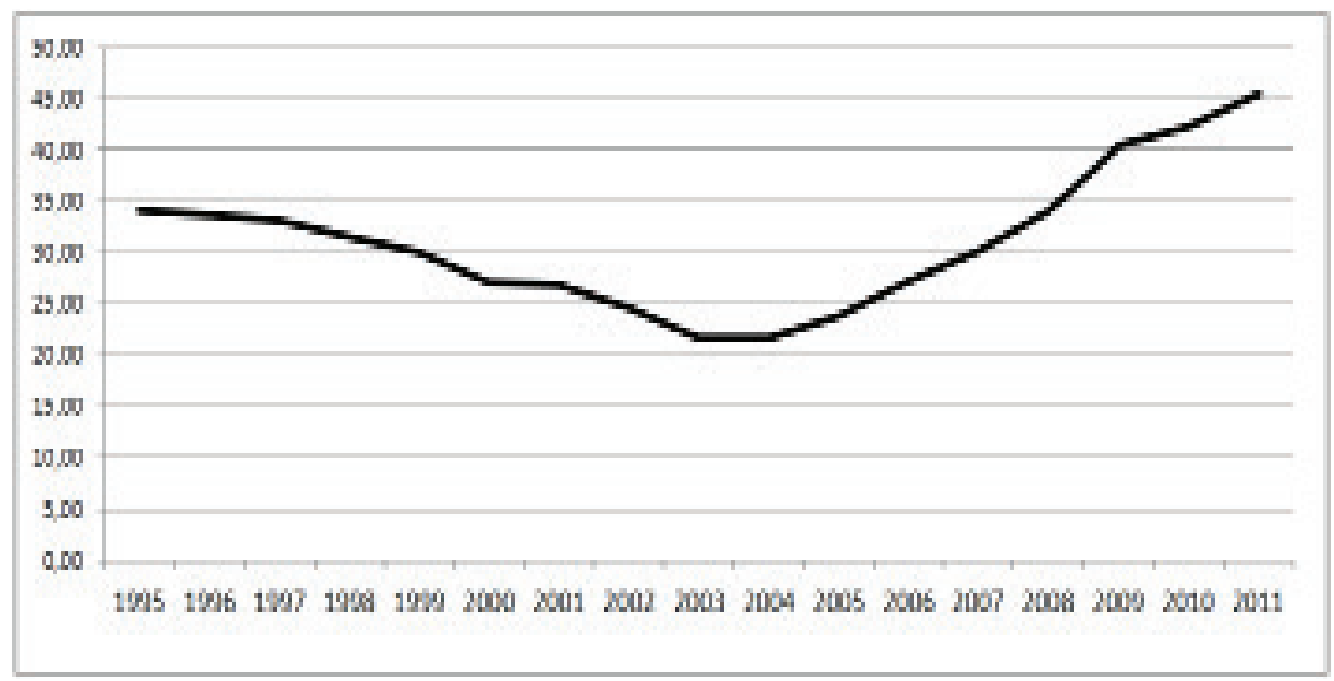

Fonte: Elaboração própria a partir de dados do Banco Central, Séries temporais e IBGE - Contas Nacionais. Série de operações de crédito totais deflacionada pelo IGP-DI, preços de 2011. Série de PIB deflacionada pelo deflator implícito do PIB, preços de 2011.

Note-se que, após 2007, não ocorre uma diminuição do crédito e isso tem a ver com o movimento anti-cíclico dos créditos dos bancos públicos. Paralelamente, podemos observar, pelo Gráfico 3, que a relação Crédito/PIB detecta a desaceleração em 2008.

Ou seja, a partir de 2004 e até o início de 2007, observa-se um ciclo ascendente, fato comentado por vários autores. É interessante aqui levantar o argumento de Hermann (2010), para quem essa expansão é resultante de fatores macroeconômicos já comentados, mas também de elementos estruturais e regulatórios. No que se refere ao primeiro fator, a autora destaca a estabilidade de preços e a gestão das políticas monetária e cambial, geradoras de maior estabilidade. Quanto ao segundo fator, ressalta-se o aumento da abertura financeira, bem como a internacionalização e a privatização dos bancos públicos, que reorganizaram o mercado, fator comentado no item anterior do trabalho. No que tange ao terceiro fator, a autora ressalta as novas tecnologias e regulações, que promovem a melhora do controle de riscos, tal como a diversificação de receitas, que dá mais flexibilidade aos bancos.

\subsection{A dinâmica do ajuste de portfólio dos bancos públicos e privados no Brasil}

Conforme comentado anteriormente, para a análise de ajuste de portfólio dos bancos, considera-se a abordagem de Minsky (1986), que relaciona a dinâmica da decisão de aplicação dos agentes com os momentos do ciclo financeiro, e os bancos estão 
inseridos nessa dinâmica, o qual eles que balizam a sua tomada de decisão, continuamente se movendo entre a dinâmica de liquidez e rentabilidade. A ideia é a de que nos momentos de expansão, há o movimento na direção de operações mais arriscadas, no sentido de serem mais ilíquidas, mas com maior potencial de rentabilidade financeira. Já nos períodos de expectativas negativas, prevalece a busca por maior liquidez em detrimento da rentabilidade. A decisão da oferta de empréstimos está articulada à essa dinâmica e à análise das operações de Ativo do Balancete dos Bancos, que permite a análise dos movimentos das aplicações. É este o sentido inicial da análise que faremos sobre a lógica de operação dos bancos que estamos analisando.

Com respeito à esse ajuste, Paula (1997) mostra que essa é essencialmente a dinâmica encontrada nos bancos que operam no país. Para além disso, a nossa consideração é a de que, no caso do Brasil, se deve destacar uma especificidade: a de que as aplicações em Títulos e Valores Mobiliários no país apresentam uma perspectiva de liquidez e também de alta rentabilidade. Ou seja, agrega-se a lógica de rentabilidade à lógica da segurança. Os bancos podem optar por aplicar em ativos líquidos e seguros (os títulos públicos) que também oferecem uma rentabilidade considerável. Ora, isso gera uma dificuldade ainda maior referente à decisão de ofertar crédito, na medida em que esse movimento só será feito se as taxas juros de ponta forem muito maiores do que a rentabilidade advinda da aplicação em títulos. Nesse sentido, a decisão de abrir mão da liquidez e da rentabilidade propiciada pelo título público vai evolver uma exigência de altas taxas de juros de ponta que, ademais, devem ainda compensar os custos operacionais.

Note-se que essa facilidade de ganhos com títulos se apresentava mais expressiva quando era possível operar através de operações de floating. É claro que o fim dessa possibilidade provocou a necessidade de ajuste por parte dos bancos. Destaque-se, no entanto, que a passagem do regime inflacionário para aquele de menor inflação não é o foco de nosso estudo. Na verdade, estaremos aqui analisando a dinâmica de ajuste dos bancos em um período em que a inflação se encontra em níveis substancialmente menores, e em que os ganhos de floating não dominam mais. Isso, no entanto, não retira a especificidade da possibilidade de altos ganhos, com risco baixo, da aplicação em títulos públicos, que permanece.

Ou seja, no que se refere ao Sistema Financeiro brasileiro, uma de suas características importantes é que, desde a década de 1970, existe a possibilidade de se gerar forte rentabilidade sem risco por meio, principalmente, de aplicações em títulos públicos, dadas as elevadas taxas de juros que esses oferecem. Em conjunturas adversas, ocorre uma rápida redução da oferta de empréstimos em direção às aplicações em títulos, sendo importante ressaltar, que tanto bancos privados nacionais quanto bancos privados estrangeiros atuam sob esta lógica (CORREA e ADATI, 2004).

O ponto a ser avançado é o de que os bancos públicos não seguiam diretamente essa dinâmica, mas vão passar a ter basicamente a mesma lógica, situação que permanecerá até 2008 . 


\subsection{A análise das contas de ativo dos balancetes dos bancos públicos e privados no Brasil}

A análise do ajuste de portfólio dos bancos requer o entendimento das contas de ativo e de passivo dos balancetes bancários. Assim sendo, faremos, a seguir, uma breve descrição de tais contas. O Banco Central as registra de acordo com as normas do Cosif (Plano Contábil das Instituições do Sistema Financeiro Nacional), sendo as mesmas listadas no Quadro 1. Isso posto, passamos a descrever as contas de ativo, que são o foco de nosso estudo.

\section{Quadro 1: Balancete dos bancos no Brasil segundo o Cosif}

\begin{tabular}{|l|l|}
\hline \multicolumn{1}{|c|}{ Passivos } & \multicolumn{1}{c|}{ Ativos } \\
\hline Circulante e Exigível a Longo Prazo & Circulante e Realizável a Longo Prazo \\
\hline - Depósitos (À vista; Caderneta de Poupança, à & - Disponibilidades \\
prazo; interfinanceiros; outros) & - Aplic. Interfinanceiras de Liquidez \\
- Captações no Mercado Aberto & - Títulos e Valores Mobiliários \\
- Recursos de Aceites e Emissões de Títulos & - Relações Interfinanceiras e Interdependências \\
- Relações Interfinanceiras e Interdependências & - Operações de Crédito \\
- Obrigações por Empréstimos e Repasses & - Outros Créditos \\
- Instrumentos Financeiros Derivativos & - Outros Valores e Bens \\
- Outras Obrigações & $\underline{\text { Permanente }}$ \\
$\underline{\text { Patrimônio Líquido }}$ & \\
\hline
\end{tabular}

Fonte: Lima (2009).

\section{Contas de ativo:}

I) Disponibilidades: consistem na conta mais líquida dos bancos, sendo constituídas pelo Caixa (recursos que estão disponíveis para saques), pelas Reservas Livres (recolhimento compulsório em espécie feito junto ao Banco Central), pelas Disponibilidades em Moeda Estrangeira e pelas Aplicações em Ouro.

II) Aplicações Interfinanceiras de Liquidez: são recursos aplicados com o intuito de cobrir deficiências de disponibilidades que possam vir a existir. Por meio dessas aplicações, os bancos geram receita utilizando seus ativos sem abrir mão de liquidez. São constituídas pelas Aplicações em Operações Compromissadas, em que um banco compra um título de outro por determinado prazo e assume o compromisso de revendê-lo ao fim do prazo estabelecido, a um preço em pouco maior do que o inicial. Assim sendo, tais operações podem ser consideradas como uma modalidade de empréstimos entre bancos e 
ocorrem no mercado aberto. As operações de overnight são operações compromissadas com prazo de vencimento de apenas um dia útil. Ademais, as Aplicações Interfinanceiras de Liquidez são compostas também pelas Operações em Depósitos Interfinanceiros (aplicações entre bancos por meio de Certificados de Depósito Interbancário), pelos Depósitos Voluntários (depósitos feitos junto ao Banco Central) e pelas Aplicações em Moeda Estrangeira no Exterior.

III) Títulos, Valores Mobiliários e Instrumentos Financeiros Derivativos: essa conta refere-se aos diversos títulos em posse do banco. Inclui também os derivativos financeiros (contratos a termo, opções e swaps), além de registrar também as operações compromissadas. Essa conta apresenta uma liquidez menor que a conta Aplicações Interfinanceiras de Liquidez, pois os títulos nela registrados, diferentemente dos títulos registrados na conta Aplicações Interfinanceiras, são recomprados pelos bancos no fim do processo.

IV) Relações Interfinanceiras: nessa conta são registradas as relações entre instituições financeiras diferentes (exemplo: sistema de compensação de cheques).

V) Relações de Interdependência: essa conta registra as transferências de recursos que ocorrem internamente a uma mesma instituição bancária (exemplo: a direção central de um banco autoriza um empréstimo, cuja realização ocorre em uma agência mais próxima ao tomador).

VI) Operações de Crédito: nessa conta são registrados os Empréstimos e Títulos Descontados, os Financiamentos, os Financiamentos Rurais e Agroindustriais, os Financiamentos Imobiliários, os Financiamentos de Infra-estrutura e Desenvolvimento. Dentre as contas do Ativo Circulante e Realizável à Longo Prazo, essa é a conta que apresenta menor liquidez. Nela estão registrados os empréstimos (não é necessário haver uma destinação pré-definida para o crédito) e os financiamentos (é necessário haver uma destinação pré-definida para o crédito) feitos pelo banco. $\mathrm{O}$ risco de inadimplência que essa conta envolve consiste na principal fonte de risco de crédito do banco.

VII) Outros Créditos: essa conta não é apenas "residual", ou seja, não é apenas uma conta que registra créditos não contabilizados na conta Operações de Crédito. A conta Outros Créditos registra também a Carteira de Câmbio do banco, na qual são contabilizadas as compras de moeda estrangeira a liquidar, os cambiais e os instrumentos à prazo em moeda estrangeira negociados pela instituição. Os empréstimos em moeda estrangeira, como os Adiantamentos de Contrato de Câmbio (ACC- o banco adianta o equivalente em reais dos dólares que serão conseguidos com a exportação) e outros empréstimos similares, também são contabilizados na Carteira de Câmbio. A conta 
Outros Créditos contabiliza também as Rendas a Receber por operações de negociação e intermediação de valores, havendo lucros para os bancos lucram resultantes de comissões e de corretagens. Assim sendo, percebe-se que as operações registradas em Outros Créditos são diferentes das registradas na conta Operações de Crédito, pois apresentam uma dinâmica diferente, vinculada ao câmbio. Portanto, quando fizermos referência, em nosso trabalho, ao crédito, estaremos nos referindo à conta Operações de Crédito.

VIII) Ativo Permanente: essa conta registra ações, ou seja, participações de caráter permanente em sociedades coligadas e controladas. A sociedade coligada de um banco com uma empresa ocorre quando esse não é acionista majoritário na empresa em que ele possui ações. A sociedade controlada ocorre quando o banco é o acionista majoritário na empresa em que ele possui ações. Ademais, o ativo permanente contabiliza, também, os bens materiais do banco (máquinas, equipamentos, bens de consumo, edificações, etc).

Quanto à análise das principais contas de ativo dos bancos, no caso dos Bancos Privados Nacionais podemos observar que, na primeira fase, houve um crescimento moderado do crédito (Gráfico 4).

Gráfico 4: Bancos Privados Nacionais - Principais contas de ativo - valores em R\$ mil

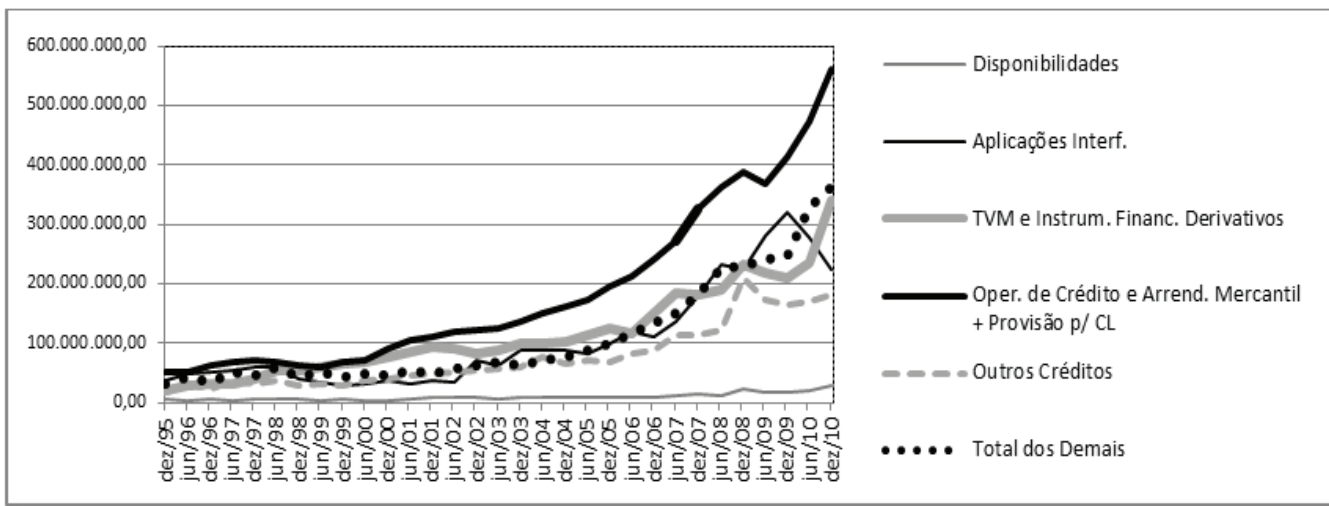

Fonte: Elaboração própria a partir de dados do Banco Central.

No que se refere ao ajuste desses bancos à dinâmica conjuntural observada no primeiro período, vemos a expansão do crédito, mas o principal movimento deu-se na lógica das aplicações com títulos e valores mobiliários. Observe-se que, para analisar essa dinâmica, devemos observar a conta TVM e também a conta Aplicações interfinanceiras de liquidez, que também contém títulos Públicos. En- 
tre 1995 e 1996, a opção foi a de concentrar mais as compras de títulos pela via da modalidade de Aplicações Interfinanceiras de Liquidez. É como se a expansão dos empréstimos estivesse sendo compensada pelo aumento desse colchão de liquidez. Paralelamente, quando eclodiu a crise da Ásia, a estratégia mudou. De fato, o ajuste dos juros domésticos se deu em níveis muito altos, no intuito de atrair de volta o capital volátil que estava saindo saído do país. Tendo em vista a magnitude dos juros que foi necessária para cobrir os níveis especulativos do Risco País e do Risco de Câmbio, a opção dos bancos privados nacionais foi a de aplicar mais em Títulos Valores Mobiliários (TVM) do que em Aplicações Interfinanceiras. Ou seja, o ganho com juros era tão grande, que compensava o direcionamento para operações que garantiam a manutenção dos títulos na carteira dos bancos no final do período, mesmo que isso fosse um pouco menos líquido do que a outra opção. Isso, ademais, se dava porque, a partir daí, passam a dominar os títulos pós-fixados Selic no perfil da dívida mobiliária e na carteira dos bancos (Lima e Corrêa, 2009).

Essa opção continuou no segundo período e permaneceu também no terceiro. Observe-se que nessas duas fases, paulatinamente as Operações de Crédito passam a crescer e o fazem com maior força depois de 2004.

No último período, pós 2007, podemos observar que, no segundo semestre de 2007, ocorre uma mudança de estratégia, com o crescimento das operações com Aplicações Interfinanceiras de Liquidez, no lugar das operações de TVM, indicando a maior busca de liquidez. O segundo movimento foi a queda das Operações de Crédito em 2008, na qual ambas as ações foram consequência dos movimentos da crise de Subprime nos Estados Unidos. Em 2010, a dinâmica se reverte de novo e volta-se à dinâmica da fase três em que as aplicações em TVM superam as de aplicações financeiras de liquidez e se observa também a expansão do crédito.

A dinâmica de ajuste de portfólio dos Bancos Estrangeiros nos mesmos períodos apresenta certa particularidade quando comparada com a dos bancos privados nacionais (Gráfico 5). Para os primeiros, também se observa uma expansão lenta do crédito até 1996. Nesses primeiros anos da análise, a dinâmica das aplicações em títulos é semelhante à observada para os bancos privados nacionais: após 1997 as operações de TVM também superam as Aplicações Interfinanceiras e esse comportamento permanece no segundo e terceiro períodos. A diferença é que o peso das Operações de Crédito foi menor no caso dos bancos estrangeiros durante todos os períodos sob análise, sendo que as operações de TVM superam os créditos entre 1997 e 2002.

Ou seja, os bancos estrangeiros foram mais agressivos do que os bancos privados nacionais na lógica de aplicações com títulos. Outra diferença importante é que os bancos estrangeiros aumentam a participação de Outros Créditos a partir de 2005 , sendo que as mesmas chegam a ter a mesma magnitude das Operações de Crédito. 
Gráfico 5: Bancos Privados Estrangeiros - Principais contas de ativo valores em R\$ mil

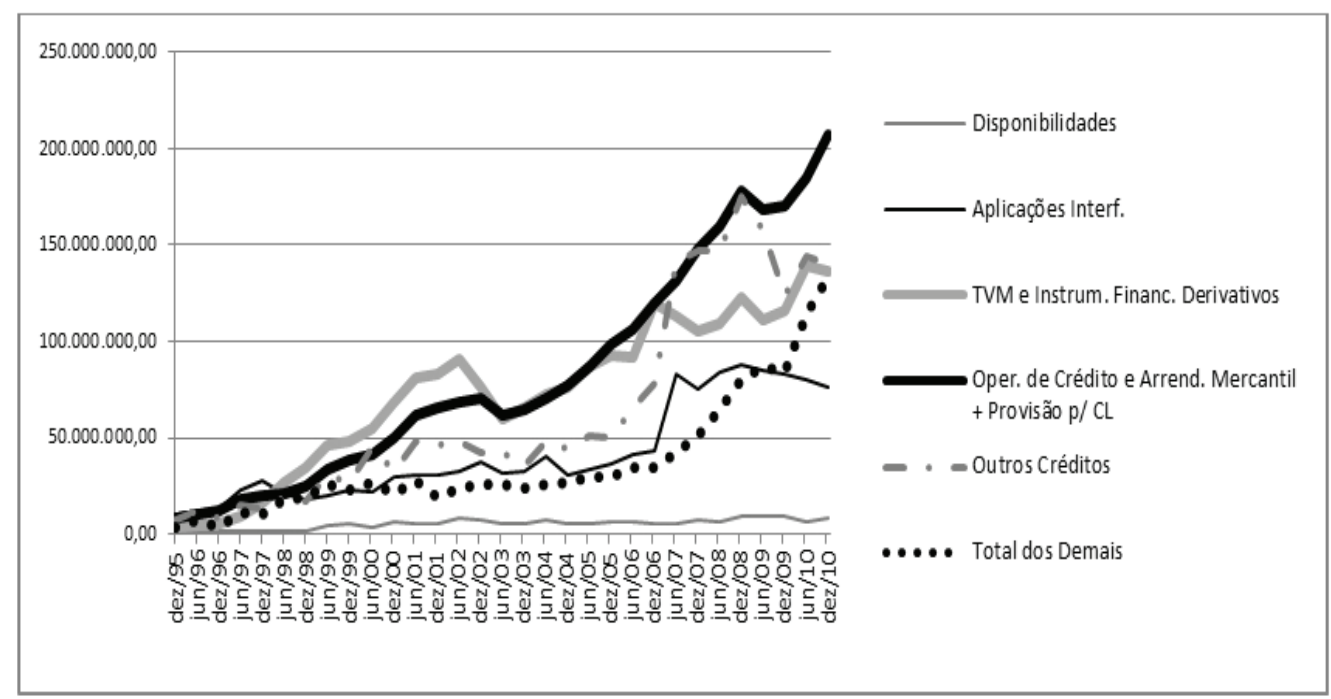

Fonte: Elaboração própria a partir de dados do Banco Central.

Lembremo-nos que nos Outros Créditos está incluída a Carteira de Câmbio do banco, que registra as compras de moeda estrangeira a liquidar efetuadas pela instituição, os cambiais e os instrumentos a prazo em moeda estrangeira negociados pelo banco. Estão aí os ACCs (Adiantamento sobre Contrato de Câmbio), que foram muito utilizados nesse período de forte crescimento das exportações, mostrando o papel dos bancos estrangeiros nesse tipo de operação. Para encerrar, cabe ainda comentar que, no último período, as Operações de Crédito caem em 2008 e, em 2010, isso se reverte de novo.

Isso posto, passemos à análise do ajuste dos Bancos Públicos (Gráfico 6). $O$ ponto fundamental a ser chamado à atenção é o de que, nos três primeiros períodos, detectamos uma mudança na forma histórica de ação desses bancos e esse é um dos aspectos que nosso trabalho tinha o intuito de levantar.

Assim como no caso dos bancos privados (nacionais e estrangeiros), as Operações de Crédito dos bancos públicos apresentaram uma expansão discreta até 1997, mas, anteriormente a isso, elas dominavam as operações de ativo. No entanto, após o advento da crise do México, essas aplicações vão caindo. Nesse interregno, paralelamente, as operações em TVM crescem expressivamente, superando, em muito, os valores das Operações de Crédito. 
Gráfico 6: Bancos Públicos - Principais contas de ativo - valores em $\mathrm{R} \$$ mil

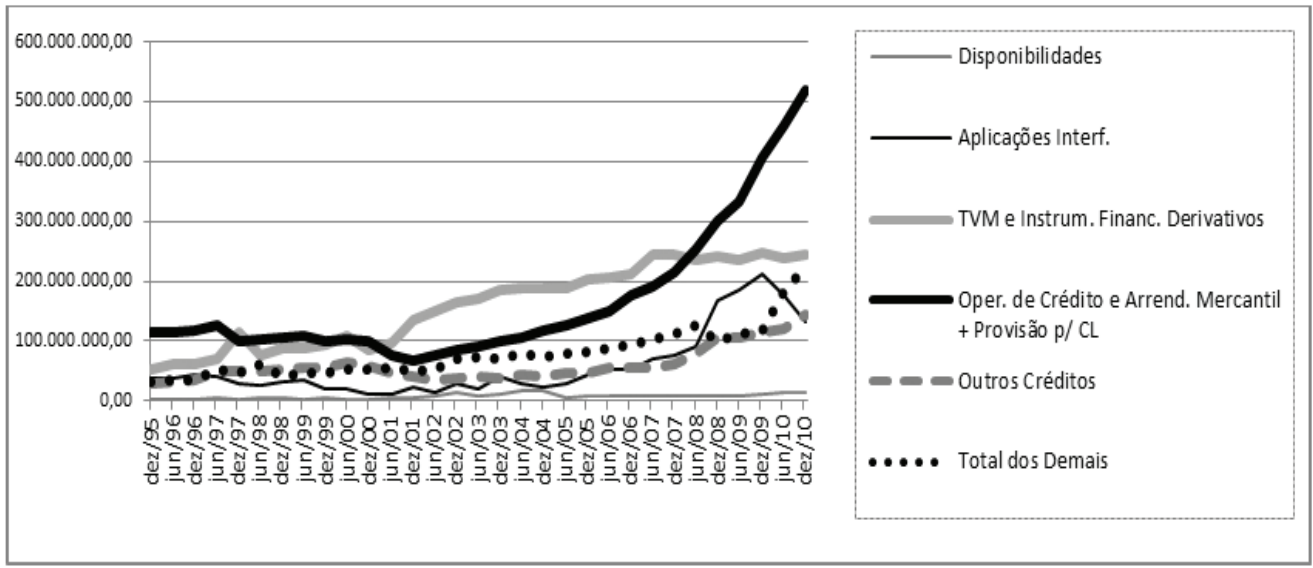

Fonte: Elaboração própria a partir de dados do Banco Central.

Ou seja, a partir do momento em que a instabilidade internacional se instaura, ainda no período de câmbio administrado (primeira fase), observa-se uma mudança na lógica de aplicações dos bancos públicos, que se aprofunda na segunda fase. De fato, na segunda fase a queda das Operações de Crédito continua ocorrendo e permanece até 2002, o que não havia ocorrido no caso dos bancos privados (nacionais e estrangeiros). Ademais, o crescimento das aplicações em TVM é expressivo e estas superam as Operações de Crédito entre 2002 e 2007. Esse fato também ocorre no caso dos bancos estrangeiros, quando somamos as aplicações em TVM com as aplicações interfinanceiras de liquidez. Nesse sentido, a trajetória de agressividade na aplicação com títulos se aproxima mais da dos bancos estrangeiros e é até mais forte do que a deles. Esse padrão se mantém durante toda a segunda fase.

Esse comportamento foi fortalecido pela regulação que estabeleceu o chamado Programa de Estímulo à Reestruturação e ao Fortalecimento do Sistema Financeiro Nacional - PROER 2 (Medida Provisória 2155/2001 - reeditada depois com o número 2196-3), sendo que várias ações estão ligadas à adequação dos bancos públicos às regras da Basiléia. $\mathrm{O}$ objetivo era o de enquadrar os bancos federais nos termos do Acordo de Basiléia, que estabelece um percentual mínimo entre o patrimônio líquido e as operações de crédito.

Além disso, o programa substituiu os empréstimos inadimplentes - chamados de empréstimos podres - por títulos públicos. A MP 2155/2001 também criou a EMGEA (Empresa Gestora de Ativos), com a função de abrigar e de administrar parte desses empréstimos podres vindos dos bancos federais. Indiretamente, a MP orientava os bancos a ter uma postura muito mais precavida quanto às operações de crédito, atuando com uma grande folga em relação aos limites 
impostos pelo Acordo de Basiléia. Uma informação importante é que grande parte desses empréstimos podres trocados por títulos foram de crédito rural (caso, por exemplo, do Banco do Brasil) e de crédito para habitação (caso da Caixa Econômica Federal), que são setores em que o sistema bancário privado, por decisão estratégica própria, não cobre, cabendo historicamente ao sistema público suprir essa deficiência.

No que se refere ao último período em estudo, nota-se que a trajetória do crédito dos Bancos Públicos torna-se mais expressiva, mas é importante observar que essa trajetória de crescimento mais forte do crédito se inicia ainda no período anterior - a partir de 2006. Só a partir de 2008, as aplicações em TVM se tornam menores que as Operações de Crédito, mas as Aplicações Interfinanceiras crescem.

De forma geral, é importante destacar, ainda, o fato de que parte dessa expansão de crédito está relacionada ao crédito consignado, criado em 2003, e ao vínculo existente entre os serviços bancários e as grandes lojas de departamento e redes varejistas.

Assim sendo, podemos considerar é que a entrada inicial de bancos estrangeiros no Brasil não levou à esperada mudança qualitativa no sistema bancário nacional. De fato, pode-se dizer que eles se adaptaram rapidamente à lógica interna e tiveram uma operação agressiva em títulos públicos nos primeiros períodos de nossa análise, sendo que, do lado da captação, ficaram fortemente endividados em dólares, só que também ofereceram empréstimos com correção pela moeda estrangeira. De forma geral, vimos então a mudança de lógica dos bancos públicos até basicamente 2006 - fase em que os mesmos se ajustam efetuando uma atuação mais agressiva em títulos públicos, em detrimento das operações de crédito.

\section{0 estudo das contas de ativo do BNB inserido no ajuste dos bancos públicos}

O objetivo dessa seção é observar a dinâmica das principais contas de ativo do Banco do Nordeste, no âmbito do ajuste dos bancos públicos no interregno analisado.

A análise das contas de ativo do BNB (gráfico 7) mostra que o domínio das Operações de Crédito no período de câmbio administrado é significativo. Ora, isso está fortemente relacionado à sua atuação de banco público regional e a principal mudança ocorre a partir do ano de 2001. A partir daí, é possível observar uma significativa mudança de performance do banco. De fato, a grande mudança começou a partir de 1999, quando as Operações de Crédito começam a cair e as operações com títulos vão aumentando. 
Gráfico 7: Banco do Nordeste - Principais contas de ativo - valores em R \$ mil

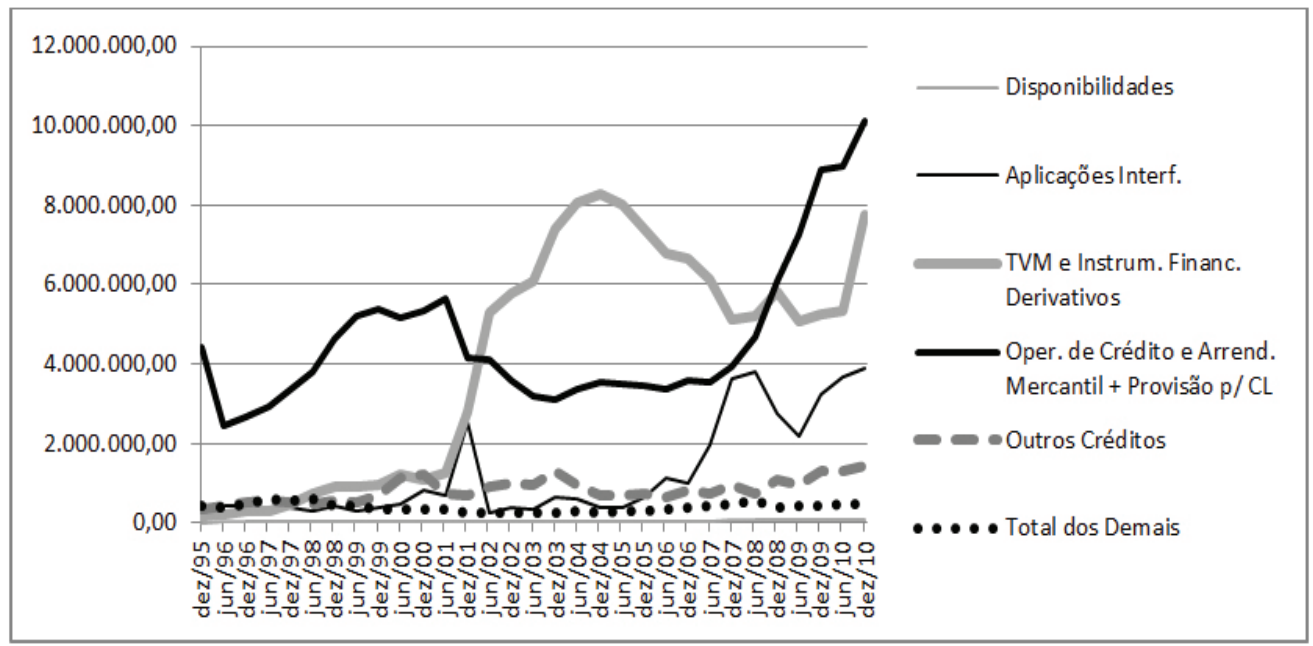

Fonte: Elaboração própria a partir de dados do Banco Central.

Note-se que, mesmo ocorrendo esse movimento, não poderíamos dizer que estava ocorrendo uma mudança de dinâmica. $\mathrm{Na}$ verdade, ela ocorreu a partir do ano de 2000, quando as operações com TVM saltam, atingindo patamares muito superiores aos anteriores, ao mesmo tempo em que as Operações de Crédito caem. Essa dinâmica permanece assim, até 2007, quando ocorreu a expansão das Operações de Crédito.

Ora, a partir destes dados a seguir vamos destacar os elementos que provocaram tais mudanças. $\mathrm{O}$ argumento é o de que tal mudança está relacionada inicialmente à regulação efetuada pelo Governo Federal, por meio do Ministério da Fazenda, de 22.06.2001, ligada ao Programa de Fortalecimento das Instituições Financeiras Federais. Essa regulação visou a adequação patrimonial dos quatro bancos públicos federais - Caixa Econômica Federal, Banco do Brasil, Banco do Nordeste e Banco da Amazônia - à legislação que definia as exigências de capital mínimo das instituições financeiras. Essa regulação ocorreu em 2001, mas está ligada à adequação das instituições financeiras federais à adesão brasileira ao acordo da Basiléia, que havia estabelecido os níveis de alavancagem para as instituições financeiras que operam no país (MENDONÇA SARTI, 2004).

A partir daí o Conselho Monetário Nacional modificou a regulamentação de tratamento de risco existente e isso provocou severos ajustes patrimoniais para as instituições financeiras, especialmente as públicas. Isso porque ficou constatado que as instituições financeiras federais, dentre elas o Banco do Nordeste, apresentavam uma estrutura de capital inadequada aos padrões internacionais.

A adequação às regras levou a mudanças importantes de atuação nos bancos públicos. A tentativa de adequação gerou a queda das operações de crédito no caso 
do BNB e do Banco da Amazônia e outro movimento que deve ter gerado foi a busca por melhores devedores (melhor classificação de crédito).

Retomando o argumento para o ajuste desses dois bancos, argumenta-se que ele tem a ver, tanto com a mudança da legislação dos Fundos Constitucionais, quanto com aspectos conjunturais de instabilidade ocorridos no interregno 1999-2003, como com a decisão do banco de se ajustar à lógica dos demais bancos.

Vejamos então os principais acontecimentos que explicariam essa mudança. Um dos elementos tem a ver com decisões políticas do próprio banco relativas à redução dos empréstimos.

Analisando-se o balancete do BNB (Gráfico 7) nota-se que, entre 1999 a 2001, há uma redução na expansão dos empréstimos que se observara na fase anterior, havendo uma certa queda dos mesmos. Para nós, isso tem a ver, em parte, com a conjuntura mais instável da época, mas, na verdade, está articulada à uma opção do banco de utilizar-se menos dos empréstimos relacionados aos recursos do Fundo Constitucional de Financiamento do Nordeste (FNE). A questão principal é a de que o FNE passa, a partir daí, a ser corresponsável pelos riscos dos empréstimos concedidos.

De fato, nessa fase os empréstimos do FNE ofertados pelo próprio Fundo (Gráfico 8) caem. Cai também o montante que o BNB toma do FNE para emprestar diretamente (em seu balancete), como fonte de recursos em seu passivo. Logicamente caem também as operações de empréstimos do banco operadas com esses recursos. Vemos então que os empréstimos do banco deixam de crescer e inclusive caem um pouco. A questão é a de que, mesmo com a baixa expansão dos créditos vinculados ao FNE, começam a serem efetuadas análises questionando o perfil das operações anteriores do BNB/FNE, questionando a "qualidade" dos empréstimos, tendo em vista a alta inadimplência que se observava.

As mudanças que ocorrem a partir do final de 2000 têm, em parte, a ver com as mudanças de imposições do Banco Central quanto às exigências de capital próprio.

As demonstrações contábeis do BNB de junho de 2000 estão analisadas pelo banco as dificuldades de adequação do mesmo a partir das regras de mudança de cálculo de adequação de capital. Isto por que Banco Central passou a determinar que as parcelas das operações do FNE correspondentes ao risco assumido pelo banco deveriam sensibilizar a sistemática de ponderação do risco e, com isto, os índices do banco passaram a ficar abaixo do limite mínimo requerido pelo Banco Central (11\%), mas dentro do estabelecido pelo acordo de Basiléia.

Nesse balancete específico, o banco questiona essa sistemática, argumentando que a inadequação é resultado da forma de contabilização, que preserva a separação dos patrimônios do banco e do FNE. Conforme a direção do banco, "o Banco do Nordeste, como órgão de desenvolvimento regional e na qualidade de agente de programas de fomento do Governo Federal, tem entre seus encargos as aplicações de recursos vinculados à programas governamentais, que, dadas as suas especifici- 
dades, independem de enquadramento às regras de alavancagem e limites definidos para as operações de crédito".

Então, se percebe que as exigências do BACEN relativas ao Programa de Fortalecimento das Instituições Financeiras Federais afetaram diretamente o Banco do Nordeste, sendo que em 2001 foram então estabelecidas medidas que fortaleceram o seu patrimônio e que permitiram que o banco se adequasse às novas exigências.

O interessante é que nessa fase há uma forte expansão do FNE (a partir de 2002) (Gráfico 8), indicando uma mudança na atuação do banco na gestão do mesmo. A hipótese de Quiante (2010) é a de que o banco ajusta seu balancete próprio e a opção passa a ser a de emprestar com os recursos do Fundo. Só que, paralelamente, a opção é a de reduzir as operações de empréstimo efetuadas pelo próprio banco (balancete próprio), operando sua ação de banco de desenvolvimento principalmente com os recursos do FNE ofertados diretamente pelo Fundo. Essa é uma mudança de estratégia da atuação do banco.

É por isto que quando se vai analisar a atuação do BNB deve-se considerar a ação do "Sistema BNB", que considera as liberações de operações de crédito do próprio banco, como também, as realizadas via a operação do FNE, em balancete próprio do Fundo.

Ainda assim, já fica a consideração de que o ajuste do balanço do BNB se deu em níveis superiores aos exigidos pelas regras da Basiléia. Tanto é verdade, que esse banco age de forma anticíclica em 2008, mudando, de novo sua forma de atuação nas operações de ativo.

\section{Evolução dos créditos de curto prazo e de longo prazo do "Sistema BNB"}

Nesta parte do trabalho, analisamos as liberações do BNB, mas agora considerando o "Sistema BNB", que leva em conta o conjunto de suas operações. Já mostramos que a lógica do mesmo foi a de expandir os recursos via liberações do FNE, em balanço próprio desse último. Somente no último período observou-se uma expansão das operações de créditos do próprio BNB. Dessa forma, optamos por analisar as liberações de crédito conjuntas do BNB e do FNE, mas separando-as em "créditos de curto prazo" e "créditos de longo prazo", a partir de dados disponibilizados pelo BNB.

As operações de crédito de curto prazo estão ligadas aos recursos operados pelo próprio $\mathrm{BNB}$ e que constam em seus balanços próprios. Já as operações de longo prazo estão fortemente ligadas aos recursos do FNE e operadas diretamente por ele. Grande parte das mesmas (mas não a totalidade) está contabilizada no balancete do FNE.

A análise do gráfico sobre a evolução das operações de crédito de curto prazo (Gráfico 8) mostra o movimento de expansão ocorrido após 2004 e a inflexão de 2007, na atuação anti-cíclica do BNB. Observa-se ainda que ocorreu uma pequena redução entre 2010 e 2011. 
Gráfico 8 - Total das operações de crédito de curto prazo do BNB -em R\$ bilhões

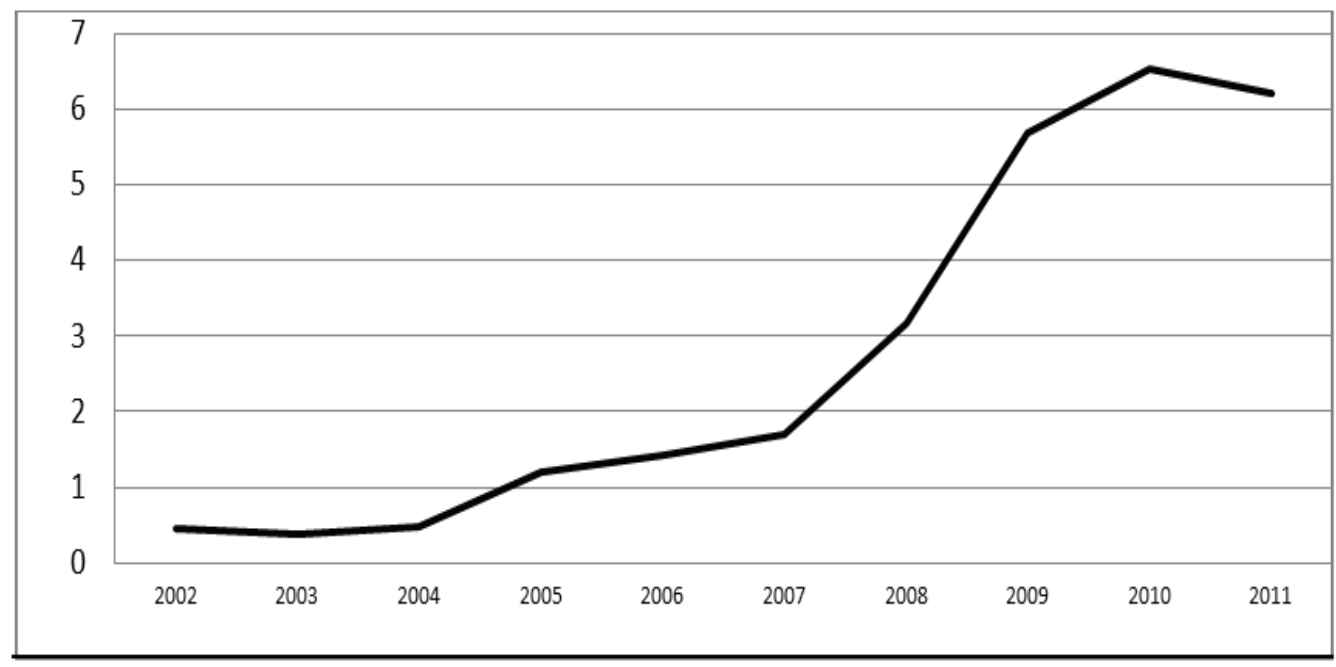

Fonte: Elaboração própria a partir de dados do BNB.

Gráfico 9: Total das operações de crédito de curto prazo do BNB por porte em $\mathrm{R} \$$ bilhões

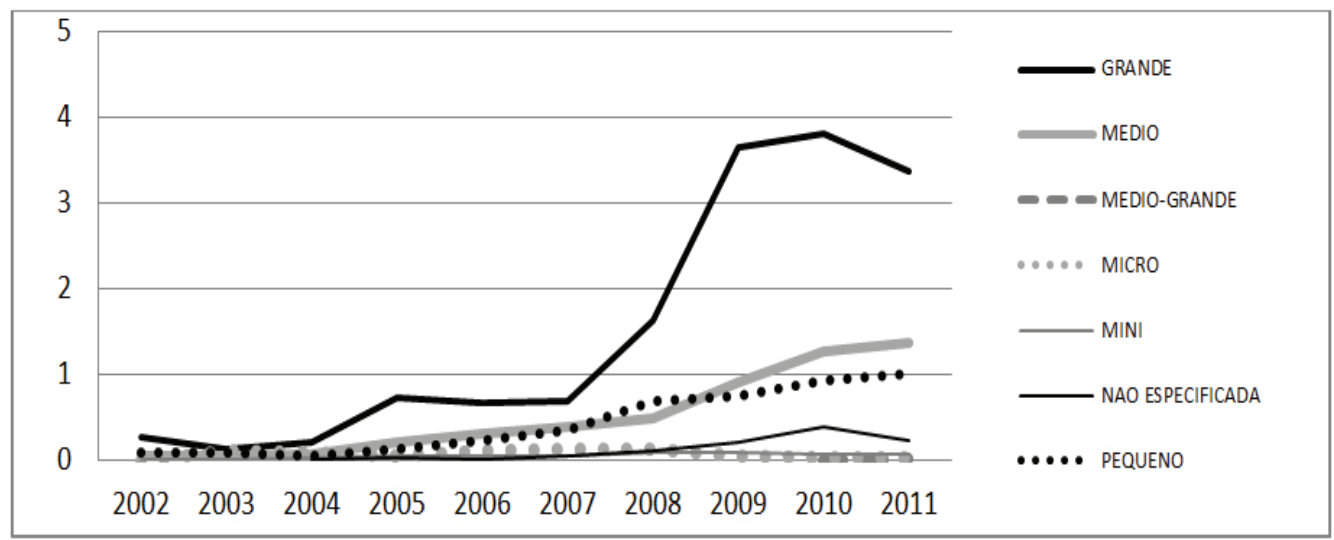

Fonte: Elaboração própria a partir de dados do BNB.

No que se refere à essas operações considerando-se o porte das mesmas, a análise do Gráfico 9 revela que, ao longo de todo o período de 2002 a 2011, a maior captação de recursos é feita pelo grande porte. Mas mais do que isso, vemos que, a partir de 2004, a expansão é puxada basicamente por eles. No caso do crescimento de 2007, o salto impressionante dos créditos de curto prazo liberados se deve a esse segmento.

Nesses termos, considerando-se as liberações agregadas, a consideração seria a de que o perfil da liberação dos créditos de curto prazo piorou. Por um lado, ela se con- 
centrou em alguns poucos estados, contemplando de forma importante o estado de São Paulo. Por outro lado, porque contemplou essencialmente os demandadores de grande porte. Ou seja, as liberações se deram fortemente para demandadores mais capitalizados.

Quanto às operações de longo prazo (Gráfico 10), vemos que a ascensão das liberações se dá a partir de 2002. Analisando a dinâmica desses créditos, vemos que entre 1999 e 2002 os mesmos diminuem, fato ligado à não liberação dos recursos do FNE que, nesses anos, apresentava retenção desses recursos. A partir de 2002, o BNB mudou sua forma de liberação dos recursos do Fundo, conforme já mencionado, e é clara a evolução desses créditos.

Ademais, nota-se também uma inflexão em 2004 e 2007, mas não com as diferenças profundas de magnitudes observadas pelo crédito de curto prazo. Conforme já comentamos, no caso do primeiro, as operações estão basicamente relacionadas à créditos e recursos que transitam pelo balancete do próprio $\mathrm{BNB}$, enquanto que as operações de longo prazo agregam os recursos do FNE. Esses recursos passaram a ser liberados com mais força, mesmo em uma fase em que o BNB ainda estava contendo suas liberações de crédito, privilegiando o ajuste interno e as operações com títulos. Nesse sentido as operações de longo prazo já haviam começado a ter taxas de crescimento mais expressivas a partir de 2002, fato ligado às liberações do PRONAF, via FNE (Fernandes, 2011). Note-se que no caso dos créditos de longo prazo não ocorre queda de recursos em 2010.

Quanto ao porte das liberações (Gráfico 11), aqui também se confirma a mesma dinâmica observada para os créditos de curto prazo: a de que são os créditos aos produtores de grande porte que lideram a captação dos recursos após 2003. No entanto, destacamos que, entre 2003 e 2006, o crédito aos mini produtores também têm uma participação importante, como também, os de médio porte. Já depois de 2007, o salto da distribuição aos grandes produtores é substancialmente maior, sendo que praticamente passa a dominar as liberações. Paralelamente, as liberações aos mini caem.

Gráfico 10: Total das operações de crédito de longo prazo do BNB- em R \$ bilhões

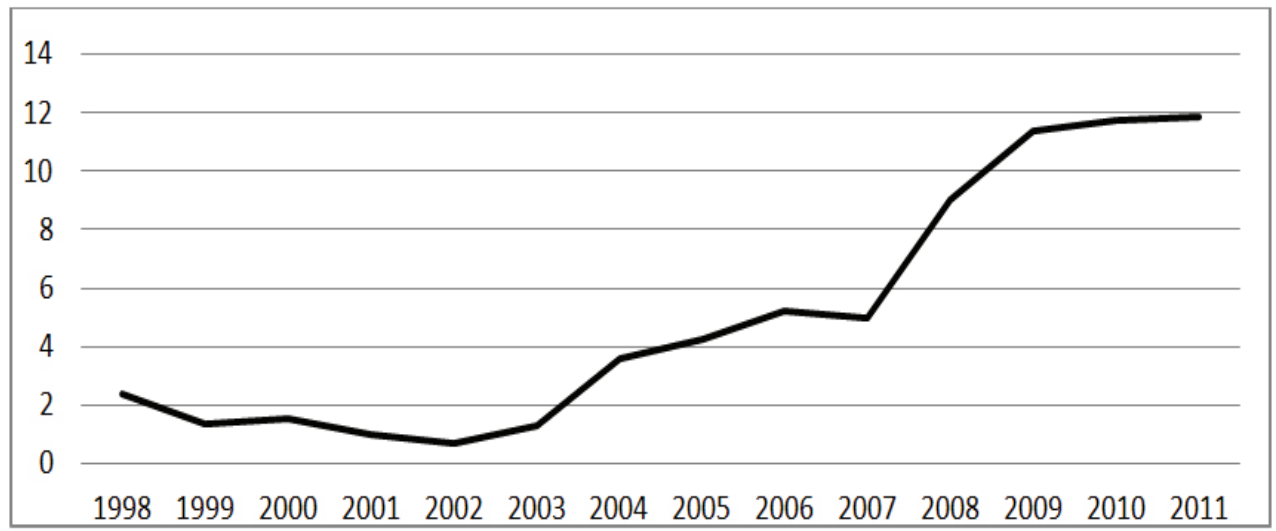

Fonte: Elaboração própria a partir de dados do BNB. 
Gráfico 11: Total das operações de crédito de longo prazo do BNB por porte em $\mathrm{R} \$$ bilhões

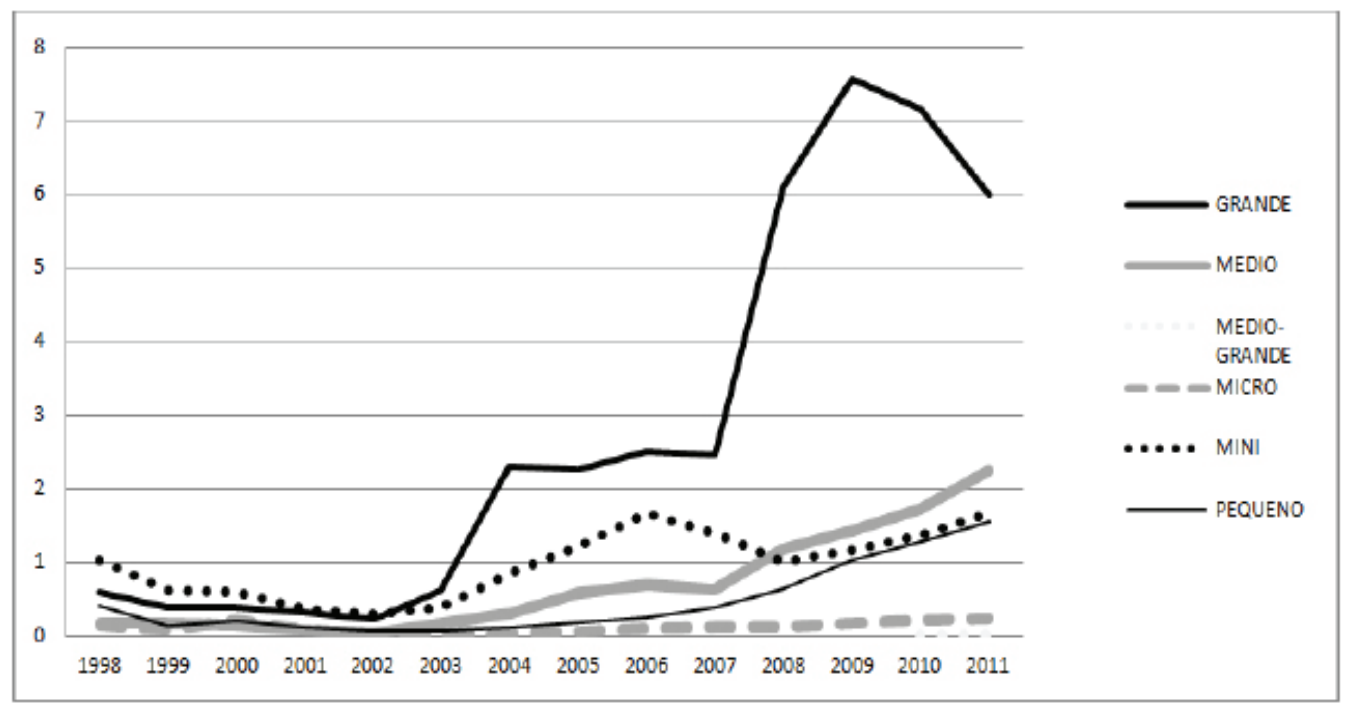

Fonte: Elaboração própria a partir de dados do BNB.

Essa foi uma importante mudança de dinâmica, pois entre 1999 e 2002, as operações direcionadas aos mini produtores haviam dominado os créditos de longo prazo e, no período seguinte, ainda representavam uma parte importante desses créditos.

Considerando esses dados, a indicação geral é a de que, a partir de 2007, houve uma piora do perfil da liberação, tanto em termos dos créditos de curto prazo quanto de longo prazo, do ponto de vista do caráter anti-concentrador que os bancos públicos poderiam ter em sua oferta de crédito. De fato, os dados deixam claro o crescimento da opção pelas operações com agentes de grande porte. Nesse sentido, o resultado mostra que o papel anticíclico dos bancos públicos foi claro, mas a opção preservou os resultados que contemplem a questão relativa ao atendimento de "bons graus de risco", que está por trás da filosófica das Regras da Basiléia.

\section{Considerações finais}

A consideração inicial de nossa análise foi o destaque do fato de que não se pode analisar o resultado das operações de crédito de um determinado banco sem considerar a lógica de ajuste de portfólio do mesmo. Nesse ponto, a perspectiva teórica que parte de Keynes, e é aprofundada por Minsky, é o ponto de partida para a compreensão da dinâmica da operação bancária. No caso dos bancos no Brasil, seguimos os trabalhos que mostram o ajuste das operações de ativo que se dá entre "Operações de Crédito", "Operações com Títulos e Valores Mobiliários” e com 
"Aplicações Interfinanceiras de Liquidez", indicando que a relação entre elas tem a ver com a dinâmica macroeconômica do país, em sua relação com o movimento dos juros e do câmbio. Ademais, indicou-se que a própria periodização dessa dinâmica está relacionada com a dinâmica da liquidez mundial.

Considerando esses fatores, mostramos o fato de que entre 1995 e 1999 a expansão dos créditos ocorreu como resposta à própria questão da queda da inflação, mas a expansão foi restrita e afetada pelas crises do México, da Ásia e da Rússia. Nesses momentos, o aumento expressivo dos juros, resultante do ajuste que sofreram para atuar contra a fuga de capitais em situação de câmbio administrado, afetou a operação de avanço do crédito, havendo uma redução dos mesmos e uma opção por aumentar as operações com Títulos e Valores Mobiliários ou com operações interfinanceiras de liquidez, que também envolve a aplicação em títulos públicos. Nota-se que esse movimento significava mais do que meramente buscar a liquidez, pois os títulos públicos brasileiros indexados à variação Selic oferecem alta rentabilidade, especialmente em momento de elevação considerável da referida taxa de juros. Nesse contexto, a possibilidade de ganhos com títulos, nos momentos em que se avizinhava a instabilidade, levava os bancos a mudarem rapidamente seu perfil de aplicação, saindo de operações de crédito e aumentando a participação com Títulos e Valores Mobiliários. Outra explicitação dessa dinâmica é a verificação do fato de que, nesses momentos, a opção dos bancos foi a de operar menos com operações interfinanceiras de liquidez (mais líquidas) e mais com operações com Títulos e Valores Mobiliários (mais lucrativas nesses momentos).

Após 1999 verificamos que os bancos privados atuam expandindo fortemente as operações de crédito, sendo que esse tipo de atuação se aprofunda após 2004, permanecendo até o segundo semestre de 2007. Foi possível notar que a crise internacional afetou a oferta de recursos, mas a mesma voltou já no final de 2009. Em linhas gerais, o que se observou foi que, após 2004, as Operações de Crédito passaram a ser mais expressivas para os bancos privados, havendo uma queda da participação das aplicações com Títulos e Valores Mobiliários. Nota-se que o movimento pró-crédito é importante. Ainda que parte expressiva esteja relacionada ao crédito pessoal (parte importante, ao crédito consignado), o que foi possível mostrar foi que os créditos em geral se expandiram: ao comércio, à indústria, à agricultura. No entanto, essa conclusão ainda não pode ser definitiva, pois o ajuste em direção à aplicação com títulos ainda é muito rápido nos momentos de mudança de conjuntura, como foi verificado em 2009.

Uma das constatações importantes da análise do ajuste de portfólio dos bancos foi a de que os bancos públicos se aproximaram da lógica de operação dos bancos privados, especialmente entre 2001 e 2007. Um dos elementos demonstrados foi o de que esse ajuste teve a ver com a implantação das regras da Basiléia. Aliás, a aplicação em títulos foi mais agressiva do que a observada nos bancos privados.

De outra parte, constatamos que os bancos públicos voltaram a ter uma operação mais ativa na oferta de créditos, tendo agido com uma atuação anticíclica importante, especialmente em 2008 e 2009. 
A partir daí, detalhamos os aspectos levantados, mas considerando o caso particular do Banco do Nordeste. No que se refere ao ajuste de portfólio desse banco, mostramos como o mesmo esteve ligado ao ajuste do banco às regras da Basiléia a partir de 2001. O ponto fulcral da constatação foi a de que o banco mudou sua atuação dessa data em diante e até 2008. O ajuste às regras da Basiléia levou a que o BNB reduzisse drasticamente suas operações de crédito com recursos próprios e aumentasse fortemente as operações com títulos. No entanto, ocorreu a expansão das operações de crédito pela via do balancete dos Fundos Constitucionais.

Nesse sentido, as operações de crédito do BNB devem considerar o "Sistema BNB". Ainda assim, o ajuste expressivo do balancete próprio do banco dá a indicação de que ele se ajustou mais do que o necessário. Tanto é verdade que, em 2008, aumentaram rapidamente suas Operações de Crédito, tendo em vista a determinação do Governo e mudaram, de novo, sua ação a favor da oferta de créditos em balancete próprio.

Ademais, por meio da análise das liberações de crédito de curto prazo e de longo prazo do $\mathrm{BNB}$, pudemos observar a manutenção da lógica concentradora da liberação de recursos: as mesmas se concentraram em alguns poucos estados e contemplaram, sobretudo, os demandadores de grande porte (mais capitalizados). Portanto, não obstante a atuação anticíclica dos bancos públicos, a opção dos mesmos preservou os resultados que contemplem a questão relativa ao atendimento de "bons graus de risco". Nesses termos, a liberação entre 2009 e 2010 respondeu o incentivo à liberação de crédito capitaneada por bancos públicos (dentre eles o Banco do Nordeste), mas a liberação foi concentradora em agentes de maior porte, indicando a piora do perfil da liberação, se considerarmos a importância que os bancos públicos devem ter no oferecimento de crédito a agentes com maiores dificuldades de captação.

\section{Referências bibliográficas}

ADATI, F. M. (2002). Mudanças recentes no Sistema Bancário Nacional - impactos sobre sua forma de atuação. Dissertação de Mestrado apresentada ao PPGE/UFU.

CORRÊA, V. P. (2010). Políticas de Crédito e Distribuição de recursos - uma análise do PRONAF. Relatório de pesquisa. IPEA. Novembro

CORRÊA, V. P.; ADATI, F. M.(2004). Mudanças no Sistema Bancário Nacional Uma análise dos impactos sobre sua forma de atuação. Anais do Encontro nacional da Sociedade Brasileira de Economia Política (SEP), 2004.

DOW, S. The treatment of money in regional economics (1993). In: DOW, S. (Ed.) Money and the economic process. Aldershot: Elgar, p.56-72. 
FERNANDES, F. F. (2011). Programa Nacional de Fortalecimento da Agricultura Familiar (PRONAF): análise da distribuição dos recursos entre 1999 e 2009. Dissertação de mestrado apresentada ao PPGE/UFU.

GARCIA, M. G. P.; DIDIER, T. (2003). Taxa de juros, risco cambial e risco Brasil. PUC-Rio.

HERMANN, J. (2010). Liberalização e Desenvolvimento Financeiro: lições da experiência brasileira no período 1990-2006 (2010). Revista Economia e Sociedade, vol. 19 , n. 2 (39), pp. 257-290, agosto.

HERMANN, J. (2010). Papel e funcionalidade dos bancos públicos: notas sobre a experiência brasileira recente (1995-2009). Anais do Congresso da Associação Keynesiana Brasileira (AKB), 2010.

IMF - International Monetary Fund (2004). Global Financial Stability Report: market developments and issues. Washington, DC: IMF, april.

IPEADATA - Disponível em http://www.ipeadata.gov.br/.

KEYNES, J. M. (1992a). Teorias alternativas da taxa de Juros in Clássicos da Literatura Econômica. Brasília: Ed IPEA.

KEYNES, J. M. (1992b). A teoria ex-ante da taxa de Juros in Clássicos da Literatura Econômica. Brasília: Ed IPEA.

KEYNES, J. M. A Teoria Geral do Emprego, do Juro e da Moeda. São Paulo: Atlas, 1982.

LIMA, H. S. R. (2009). Transformações recentes no Sistema Bancário Nacional (1995-2007): bases teóricas, ajustes de portfólio e evidências empíricas. Dissertação de mestrado apresentada ao PPGE/UFU. Uberlândia, 2009.

LIMA, H. S. R.; CORRÊA, V. P. (2009). O ajuste de portfólio dos bancos no Brasil segundo seu controle patrimonial. Anais do Congresso da Associação Keynesiana brasileira (AKB).

MENDONÇA SARTI, A. R. R. (2004) O Acordo de Basileia de 2004: uma revisão em direção às práticas de mercado, Economia Política Internacional: análise estratégica, n. 2. CERI. Campinas: IE/Unicamp, julho a setembro, p. 27-37. 
MIGUEL, P. P. (2001). Paridade de Juros, Fluxo de Capitais e Eficiência do Mercado de Câmbio no Brasil: evidência dos anos 90. Dissertação apresentada ao Departamento de Economia da Faculdade de Economia, Administração e Contabilidade da Universidade de São Paulo.

MINSKY, H. P. (1986). Stabilizing an unstable economy. New Haven, London: Yale University Press.

PAULA, L. F. (1997). Comportamento dos bancos em alta inflação: teoria e experiência brasileira recente. Tese de doutorado. Campinas: Unicamp/IE.

PAUlA, L. F. R.; ALVES JÚNIOR, A. J.; MARQUES, M. B. L.(2000). Ajuste Patrimonial e padrão de rentabilidade dos bancos privados no Brasil durante o Plano Real. Anais do Encontro Nacional da Sociedade Brasileira de Economia Política (SEP), 2000.

PRATES, D. M. (2002). Crises financeiras dos países 'emergentes': uma interpretação heterodoxa. Tese de doutorado. Campinas: Unicamp/IE.

PUGA, F. P.(1999). Sistema Financeiro Brasileiro: Reestruturação Recente, Comparações Internacionais e Vulnerabilidade à Crise Cambial. BNDES (mimeo).

QUIANTE, W. (2010). Fundos Constitucionais e Banco do Nordeste - uma análise das liberações considerando a lógica operacional do Sistema Bancário Nacional. Dissertação de mestrado apresentada ao PPGE/UFU.

Recebido em 01.07.16

Aprovado em 19.08.16 